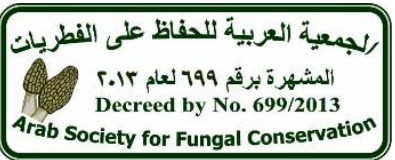

Contents lists available at Egyptian Knowledge Bank

Microbial Biosystems

Journal homepage: http://mb.journals.ekb.eg/

\title{
Role of IgD in prevention and treatment of SARS CoV-2 infection "The Unknown Soldier"
}

\section{Sheir DH*}

Chemistry of Natural and Microbial Products Department, Pharmaceutical Industries Researches Division, National Research Centre, Dokki, 12622, Egypt.

\author{
ARTICLE INFO \\ Article history \\ Received 21 June 2020 \\ Received revised 28 June 2020 \\ Accepted 2 July 2020 \\ Available online 5 July 2020 \\ (C) Sheir 2020 \\ Corresponding Editor: \\ Abo Nahas HH \\ Balbool BA \\ Keywords \\ Antibody therapy \\ COVID-19 \\ Vaccine alternative \\ Half-life elongation of Ig D \\ Recombinant monoclonal antibodies
}

\begin{abstract}
COVID-19 presents varied clinical features, ranging from asymptomatic, mild, to acute respiratory distress syndrome (ARDS). People of any age can be infected by the novel coronavirus but some people are at more risk than others of becoming seriously ill with COVID-19. Older people, and people with pre-existing medical conditions (such as asthma, diabetes, and heart disease) appear to be more vulnerable developing severe or even lethal illness. Children can be infected with SARS-CoV-2, and become ill with COVID-19. However, they appear to be less susceptible to infection than adults and their symptoms are generally milder. Immunoglobulin D (IgD) has remained an enigmatic antibody class since its discovery more than 50 years ago. The function of secreted $\operatorname{IgD}$ has been a longstanding puzzle in immunology. In this pandemic, it is the proper time to rediscover its role and find additional therapy to vaccine. In this article I will review IgD discovery, its role in immunity, its concentration in some groups and their susceptibility to infection with COVID 19.
\end{abstract}

Published by Arab Society for Fungal Conservation

\section{Introduction}

Antibodies or immunoglobulins (Ig) are formed by plasma cells as a humoral immune response to antigens. The first antibodies formed after antigen stimulation are of the IgM class, followed later by $\operatorname{IgG}$ and also $\operatorname{IgA}$ antibodies. $\operatorname{IgD}$ normally occurs in serum in trace amounts. The immunoglobulin $\mathrm{G}(\mathrm{IgG})$, is the most abundant antibody isotype in the plasma of the humoral immune response accounts for about $75 \%$ of the total Igs of healthy individuals, it detoxifies harmful substances and is important in the recognition of antigen-antibody complexes by leukocytes and macrophages. IgM usually circulates in the blood, accounting for about $10 \%$ of human immunoglobulins and it is first produced in response to microbial infection/antigen invasion by $\mathrm{B}$ cells. $\operatorname{Ig} \mathrm{A}$ is abundant in nasal mucus, saliva, serum, breast milk, and intestinal fluid, accounting for $10-15 \%$ of human immunoglobulins. IgE is present in minute amounts, accounting for no more than $0.001 \%$ of human immunoglobulins and its original role is to protect against parasites. While $\operatorname{IgD}$ accounts for less than $1 \%$ of human immunoglobulins and it is may be involved in the induction of antibody production in B cells, but its exact function still unknown (Schroeder and Cavacini, 2010).

Immunoglobulin $\mathrm{D}(\mathrm{IgD})$ was discovered in a patient with myeloma more than 50 years ago and remains as the most enigmatic of immunoglobulin classes (Chen and Cerutti 2010). The relative molecular mass and half-life of secreted $\operatorname{IgD}$ is $185 \mathrm{kDa}$ and 2.8 days, respectively (Rogentine et al 1966). IgD exists in two forms. On the one hand, $\operatorname{IgD}$ is coexpressed with IgM on the surface of mature B cells before antigenic stimulus, as a receptor for 
that antigen (Finkelman et al. 1976; Ruddick and Leslie 1977) and this may explain the success of plasma of recovered patients in some cases of COVID 19 patients. Blood plasma should be collected within 28 days after recovery; therefore, it is suggested to be collected within 3 days after recovery to guarantee the presence of $\operatorname{IgD}$, and on the other, free $\operatorname{IgD}$ circulates in the blood where it represents $<1 \%$ of total immunoglobulin content. Serum $\mathrm{IgD}$ can participate in anti-infectious immunity and immune regulation (Vladutiu 2000; Chen and Cerutti 2011; Rigante 2016).

\section{Discovery of IgD}

In 1964, physicians David Rowe and John Fahey identified and characterized an unusual myeloma protein in humans while studying multiple myeloma disease with electrophoretic and metabolic properties different from the known Ig classes at that time (Rowe and Fahey 1965 a,b). The myeloma protein displayed no reactivity to the antisera against IgM, IgG, or IgA. They suggested that this myeloma protein represented a member of a novel Ig class rather than an abnormal product of the malignant myeloma cells (Rowe and Fahey 1965 a,b). In the late 1970s and early 1980 s, IgD was discovered in primates, rodents, and selected species of mammals, including dog, mouse, rat, rabbit, and guinea pig, whereas it was undetectable in other mammals, such as swine, birds, cattle, sheep, and pig (Finkelman et al. 1976; Chen et al. 1982; Preud'homme et al. 2000; Stavnezer et al. 2008). More importantly, IgD and its homologs and orthologs have recently been found in a wide spectrum of species that are evolutionarily much more ancient, such as cartilaginous fishes, bony fishes, amphibians, and reptiles with the exception of birds (Preud'homme et al. 2000; Stenvik et al. 2001). These findings demonstrated that $\operatorname{IgD}$ is indeed an ancient because the cartilaginous fishes appeared on earth as many as some 470 million years ago, when jawed vertebrates first evolved and adaptive immune systems first appeared.

$\mathrm{IgD}$ is present in plasma and also in human nasal, lacrimal, salivary, mammary, bronchial, pancreatic, and cerebrospinal fluids (Brandtzaeg et al. 1979a; Korsrud and Brandtzaeg 1980) and in the amniotic fluid of pregnant women with concentrations progressively increasing during the first half of pregnancy (Cederqvist et al. 1978) Only trace amounts of $\mathrm{IgD}$ are present in intestinal mucosal secretions (Brandtzaeg et al. 1979a; 1979b; Brandtzaeg and Korsrud 1984; Bjerke et al. 1986). The distribution of soluble $\operatorname{IgD}$ largely correlates with the distribution of IgD-producing B cells. Intestinal mucosa, liver, peripheral lymph nodes, spleen, and bone marrow contain very few IgD producing B cells, while tonsils, adenoids, salivary, and lachrymal glands, and nasal mucosa harbor abundant IgD-producing B cells (Brandtzaeg et al. 1979a, 1979b; Korsrud and Brandtzaeg 1980; Plebani et al. 1983; Korsrud and Brandtzaeg 1981; Brandtzaeg 1989; Chen et al. 2009). IgD-producing B cells can account for up to $20 \%$ of all Ig-secreting cells in human tonsils (Chen et al. 2009; Liu et al.1996; Arpin et al. 1998). The reason why they are rarely found in bone marrow and gut associated-lymphoid tissues (GALTs) in healthy individuals is probably because they are not normally generated there and they express a homing profile not in favor of the intestinal mucosa (Johansen et al. 2005). The numbers of $\mathrm{IgD}$-producing $\mathrm{B}$ cells in the upper aerodigestive mucosa are drastically increased in patients with IgA deficiency (Brandtzaeg and Nilssen 1995; Brandtzaeg 1995; Brandtzaeg et al. 2005). However, cellassociated $\operatorname{IgD}$ includes transmembrane $\operatorname{IgD}$, intracellular $\operatorname{IgD}$, and secreted $\operatorname{IgD}$ bound to various cell types. Crosslinking of $\operatorname{IgD}$ receptor on $\mathrm{T}$ cells was shown to protect T cells from apoptosis (Tamma and Coico 2003). It has also been shown that this $\mathrm{IgD}$ receptor could promote the formation of immune synapse between cognate $T$ cells and naïve $\mathrm{B}$ cells that express transmembrane $\operatorname{IgD}$ and thereby boost antigen presentation and antibody production (Wu et al. 1999; Tamma et al. 2001). Moreover, IgD can largely increase in B cells, in which $\operatorname{IgM}$ function is suppressed, suggesting that $\operatorname{IgD}$ is largely able to substitute for IgM functions (Lutz et al. 1998). In addition, previous studies have showed that the association of secretory $\operatorname{IgD}$ with basophils and mast cells results in the production of antimicrobial factors and the enhancement of respiratory immune resistance (Chen et al. 2009; Edholm et al. 2010).

\section{Role of IgD as an immunomodulator}

The function of secreted $\operatorname{IgD}$ has been a longstanding puzzle in immunology. Secreted IgD can bind to many pathogenic microorganisms and their products, many of which are virulence factors used in pathogenesis, such as measles virus, Haemophilus influenzae adhesin MID (Hag), Moraxella catarrhalis, rubella virus, diphtheria toxin, Escherichia coli, streptococci streptolysin O (Heiner and Rose 1970; Luster et al. 1976; Swierczynska et al. 1976; Jefferis and Mathews 1977; Sewell et al. 1978; Salonen et al. 1985; Forsgren et al. 2001; Ronander et al. 2008; Chen et al. 2009). Most of these pathogens infecting same anatomic location where $\operatorname{IgD}$ is abundant, i.e. the upper aerodigestive MALTs, strongly supports the concept that $\operatorname{IgD}$ has protective functions against these pathogens perhaps by contributing to immune exclusion or neutralization. Also, serum $\operatorname{IgD}$ was increased in patients with leprosy (Sirisinha et al. 1972), tuberculosis (Buckley and Trayer 1972; Kikindjanin 1981), salmonellosis, infectious hepatitis (Rostenberg and Penaloza 1978), and malaria (Colwell et al. 1971). 


\section{Risk factors for Covid 19 and role of IgD}

Adults aged over 70 and those underlying health conditions such as respiratory, cardiovascular disease, diabetes, chronic respiratory disease, hypertension, and cancer were all associated with an increased risk of death in addition to obesity. However, It was found a linear increase of $\operatorname{IgD}$ until the age of 10 (Jankowski 1980), followed by a gradual decrease until the age of 14 (Geny et al. 1974) and then steadily decreased with age in adults which correlates with a gradual decline of immunity in older people (Tietz et al. 1992; Haraldsson et al. 2000; Listi et al. 2006). However, some studies found to be restricted to females (Mosedale et al. 2006). Moreover, Serum IgD concentrations were significantly lower in overweight individuals than in those with normal weight. On the other hand, the concentration of IgD showed considerable biological variation, even in people of the same age, from undetectable to $400 \mathrm{mg} / \mathrm{liter}$ (Rowe et al. 1968; Dunnette et al. 1977).

On the other hand, myeloma patients are considered to be safe from COVID-19 as reported by Researchers in the IMF's Asian Myeloma Clinical Trials Network (AMN). AMN sites in Beijing; Shanghai; Korea (with multiple myeloma centers); Singapore; and Japan (through the Japanese Myeloma Society), report zero cases of COVID-19 in myeloma patients and no COVID-19-related deaths. In Korea, there were, for example, 109 overall COVID-19 deaths, but none for myeloma patients. In Singapore, only 2 deaths (in total), and in Japan, a total of 52 in the hard-hit areas of Italy, Spain, and France. However, the numbers are relatively small. In Italy, patients and deaths have been in elderly patients late in the disease. Consideration should be taken if they have subjected to chemotherapy or stem cell transplantation. Allergic diseases, asthma, and COPD are not risk factors for SARS-CoV-2 infection. However, there is many intriguing connections of secreted $\operatorname{IgD}$ with myeloid cells. Early studies showed that granulocytes, such as neutrophils and eosinophils, could bind significant levels of $\operatorname{IgD}$ under certain pathological conditions, such as skin allergy and inflammation (Hunyadi et al. 1976; Dikeacou et al. 1979), although they bound little $\operatorname{IgD}$ under physiological conditions (Lawrence et al. 1975; Berretty and Cormane 1979; Walsh and Kay 1986).

Although the first commercial $\mathrm{mAb}$ was an antirespiratory syncytial virus (RSV) antibody used to fight a pediatric respiratory illness, they were widely utilized for long time in cancer and inflammatory disease (Beck 2010; Reichert 2015; Vacchelli 2013) till recently a flurry of human, or humanized, mAbs against cytomegalovirus (CMV), dengue virus, Ebola virus, H5N1 influenza virus, Hendra virus, hepatitis $\mathrm{C}$ virus (HCV), herpes simplex virus (HSV), human immunodeficiency virus (HIV), Marburg virus, Nipah virus, rabies virus, severe acute, respiratory syndrome (SARS) virus, West Nile virus and yellow fever virus have been described in the past few years (Bossart 2009; Berry and Gaudet 2011; Krawczyk et al. 2013; Dejnirattisai et al. 2015; Flyak et al. 2015; Tan 2015). Some of these mAbs are currently being tested in the clinic and include second-generation mAbs with improved neutralizing activity and/or novel target specificities (Both 2013; Corti and Lanzavecchia 2013; Cohen 2013; Klein 2013; Kwong et al. 2013; Euler and Alter 2014; Huang et al. 2014). Finally, antiviral mAbs have already demonstrated partial efficacy when administered after HIV, HCV, or Ebola virus established infections but the neutralizing mAbs was broadly applied in case of HIV that mAbs represent promising, high-addedvalue therapeutic agents (Barouch 2013 ; Flego 2013; de Jong 2014 ; Qiu 2014).

\section{Advantages of using Recombinant monoclonal antibodies (rAbs)}

The main obstacle of using $\operatorname{IgD}$-its short half-life (2.8 days) can be overcomed by using Recombinant monoclonal antibodies (rAbs). Producing rAbs is cheaper than generating mAbs. Indeed, rAbs required less purified antigen to produce than classical mAbs. Moreover, the production time is shorter (weeks vs. months). Mass production of rAbs does not required the use of animals (overcomes ethical concerns). rAbs can be produced in several formats like Fab fragments, single-chain variable region fragments $(\mathrm{ScFv})$, diabodies (Dimeric ScFvs) and in several hosts (from bacteria to human cells). We can switch the antibodies of species (from mouse to human), of classes (from IgG to IgE) and of substypes (from an entire $\mathrm{IgG}$ form to $\mathrm{ScFv}$ ) with no immeasurable effort. rAbs offer the specificity and the reproducibility of mAbs with the advantage of recombinant modifications readily available. Thus, they can be used in all applications where classical mAbs are used. rAbs are constructed in vitro, outside the constraints of the immune system, using recombinant DNA technologies. The antibody genes are isolated and then incorporated into plasmid DNA vectors, and the resulting plasmids are transformed or transfected into expression hosts such as bacteria, yeast, or mammalian cell lines (similar process to classical recombinant protein production). However, Motavizumab has a serum half-life of approximately 24 days in children. Study of a humanized monoclonal antibody engineered to have increased binding affinity to FcRn to extend the serum half-life in humans. In healthy adult subjects, inclusion of the YTE mutation in the Fc domain of motavizumab (mota-YTE) decreased clearance by $71 \%$ to $86 \%$ and increased serum half-life 2- to 4-fold (up to 100 days) compared with the parent antibody, motavizumab (Robbie et al. 2013). 


\section{Conclusion}

Further studies are needed to prove the results and statistics of the previous studies and also elongation the $\mathrm{t} 1 / 2 \mathrm{of} \operatorname{IgD}$.

\section{References}

Arpin C, de Bouteiller O, Razanajaona D, Fugier-Vivier I, Brière F, Banchereau J, Lebecque $\mathrm{S}$, Liu YJ (1998) The normal counterpart of IgD myeloma cells in germinal center displays extensively mutated $\mathrm{IgVH}$ gene, CmuCdelta switch, and lambda light chain expression. J Exp Med 187:1169-1178. https://doi.org/10.1084/jem.187.8.1169

Barouch DH (2013) Therapeutic efficacy of potent neutralizing HIV-1-specific monoclonal antibodies in SHIV-infected rhesus monkeys. Nature 503:224-228. https://dx.doi.org/10.1038\%2Fnature 12744

Beck A (2010) Strategies and challenges for the next generation of therapeutic antibodies. Nat Rev Immunol 10:345-352. https://doi.org/10.1038/nri2747

Berretty PJ, Cormane RH (1979) Immunofluorescence studies on eosinophilic granulocytes. $\mathrm{Br} \mathrm{J}$ Dermatol 101:309-314.

https://doi.org/10.1111/j.1365-2133.1979.tb05624.x

Berry JD, Gaudet RG (2011) Antibodies in infectious diseases: polyclonals, monoclonals and niche biotechnology. Nat Biotechnol 28:489-501. https://doi.org/10.1016/j.nbt.2011.03.018

Bjerke K, Brandtzaeg P, Rognum TO (1986) Distribution of immunoglobulin producing cells is different in normal human appendix and colon mucosa. Gut 27: 667-674. https://doi.org/10.1136/gut.27.6.667

Bossart KN (2009) A neutralizing human monoclonal antibody protects against lethal disease in a new ferret model of acute nipah virus infection. PLoS Pathog 5:e1000642. https://doi.org/10.1371/journal.ppat.1000642

Both L (2013) Monoclonal antibodies for prophylactic and therapeutic use against viral infections. Vaccine 31:15531559. https://doi.org/10.1016/j.vaccine.2013.01.025

Brandtzaeg P, Carlsen HS, Farstad IN (2005) The human mucosal B-cell system. In: Mestecky J, Lamm ME, Strober W, Bienenstock J, McGhee JR, Mayer L (eds). Mucosal Immunology. Amsterdam: Elsevier Academic Press.

Brandtzaeg P, Surjan L Jr, Berdal P (1979a) Immunoglobulin-producing cells in clinically normal, hyperplastic and inflamed human palatine tonsils. Acta Otolaryngol Suppl (Stockh) 360:211-215. https://doi.org/10.3109/00016487809123519

Brandtzaeg P, Gjeruldsen ST, Korsrud F, Baklien K, Berdal P, Ek J (1979b) The human secretory immune system shows striking heterogeneity with regard to involvement of $\mathbf{J}$ chain-positive $\mathrm{IgD}$ immunocytes. $\mathbf{J}$ Immunol 122:503-510.
Brandtzaeg P, Korsrud FR (1984) Significance of different $\mathrm{J}$ chain profiles in human tissues: generation of $\operatorname{IgA}$ and IgM with binding site for secretory component is related to the $\mathbf{J}$ chain expressing capacity of the total local immunocyte population, including $\operatorname{IgG}$ and $\operatorname{IgD}$ producing cells, and depends on the clinical state of the tissue. Clin Exp Immunol 58:709- 718.

http://www.ncbi.nlm.nih.gov/pmc/articles/pmc1577102

Brandtzaeg P, Nilssen DE (1995) Mucosal aspects of primary B cell deficiency and gastrointestinal infections. Curr Opin Gastroen 11:532-540. http://www.ncbi.nlm.nih.gov/pubmed/4205532

Brandtzaeg P (1989) Overview of the mucosal immune system. Curr Top Microbiol Immunol 146:13-25. https://doi.org/10.1007/978-3-642-74529-4_2

Brandtzaeg P (1995) The role of humoral mucosal immunity in the induction and maintenance of chronic airway infections. Am J Respir Crit Care Med 151:2081-2086. Discussion 2086-2087. https://doi.org/10.1164/ajrccm.151.6.7767561

Buckley CE, Trayer HR (1972) Serum IgD concentrations in sarcoidosis and tuberculosis. Clin Exp Immunol 10:257-265.

http://www.ncbi.nlm.nih.gov/pmc/articles/pmc1713174/ Cederqvist LL, Ewool LC, Bonsnes RW, Litwin SD (1978) Detectability and pattern of immunoglobulins in normal amniotic fluid throughout gestation. Am J Obstet Gynecol 130:220-224. https://doi.org/10.1016/00029378(78)90370-8

Chen CL, Lehmeyer JE, Cooper MD (1982) Evidence for an IgD homologue on chicken lymphocytes. J Immunol 129:2580-2585.

http://www.ncbi.nlm.nih.gov/pubmed/6183338

Chen K and Cerutti A (2010) New Insights into the Enigma of Immunoglobulin D. Immunol Rev 237(1): 160-179. https://doi.org/10.1111/j.1600-065x.2010.00929.x

Chen K, Cerutti A (2011) The function and regulation of immunoglobulin D. Curr Opin Immunol 23:345-52. https://doi.org/10.1016/j.coi.2011.01.006

Chen K, Xu W, Wilson M, He B, Miller NW, Bengten E, Edholm E-S, Santini PA, Rath P, Chiu A, Cattalini M, Litzman J, Bussel J, Huang B, Meini A, Riesbeck K, Cunningham-Rundles C, Plebani A and Cerutti A (2009) Immunoglobulin D enhances immune surveillance by activating antimicrobial, proinflammatory and B cell-stimulating programs in basophils. Nat Immunol10: 889-898. https://dx.doi.org/10.1038\%2Fni.1748 
Cohen J (2013) Immunology. Bound for glory. Science 341:1168-1171.

https://doi.org/10.1126/science.341.6151.1168

Colwell EJ, Bernier GM, Fife EH Jr (1971) Serum immunoglobulin D and malaria antibodies in South Vietnamese residents. Trans $\mathrm{R}$ Soc Trop Med Hyg 65:310-314.

Corti D, Lanzavecchia A (2013) Broadly neutralizing antiviral antibodies. Annu Rev Immunol 31:705-742. https://doi.org/10.1016/0035-9203(71)90005-8

de Jong YP (2014) Broadly neutralizing antibodies abrogate established hepatitis C virus infection. Sci Transl Med 6:254:254ra29.

https://dx.doi.org/10.1126\%2Fscitranslmed.3009512

Dejnirattisai W, Wongwiwat W, Supasa S, Zhang X, Dai X, Rouvinski A, Jumnainsong A, Edwards C, Quyen N, Duangchinda T, Grimes JM, Tsai WY, Lai CY, Wang WK, Malasit P, Farrar J, Simmons CP, Zhou ZH, Rey FA, Mongkolsapaya J, Screaton GR (2015) A new class of highly potent, broadly neutralizing antibodies isolated from viremic patients infected with dengue virus. Nat Immunol 16:170-177. https://doi.org/10.1038/ni.3058

Dikeacou TC, van Joost T, Cormane RH (1979) The recruitment of inflammatory cells using the skin-window technique. Arch Dermatol Res 265:1-7.

https://doi.org/10.1007/bf00412695

Dunnette S, Gleich GJ, Weinshilbourn RM (1978) Inheritance of low serum immunoglobulin D. J Clin Invest 62:248-255. https://doi.org/10.1172/JCI109123

Dunnette SL, Gleich GJ, Miller RD, Kyle RA (1977) Measurement of $\mathrm{IgD}$ by a double antibody radioimmunoassay: demonstration of an apparent trimodal distribution of $\operatorname{IgD}$ levels in normal human sera. J Immunol 119:1727-1731. PMID: 915276

Edholm ES, Bengten E, Stafford JL, Sahoo M, Taylor EB, Miller NW, Wilson M (2010) Identification of two IgD B cell populations in channel catfish, Ictalurus punctatus. J Immunol $1854082 \mathrm{e} 4094$.

https://doi.org/10.4049/jimmunol.1000631

Euler Z, Alter G (2014) Exploring the potential of monoclonal antibody therapeutics for HIV-1 eradication. AIDS Res Hum Retroviruses 31:13-24.

https://doi.org/10.1089/aid.2014.0235

Finkelman FD, van Boxel JA, Asofsky R, Paul WE (1976) Cell membrane $\operatorname{IgD}$ : demonstration of $\operatorname{IgD}$ on human lymphocytes by enzyme-catalyzed iodination and comparison with cell surface Ig of mouse, guinea pig, and rabbit. J Immunol 116:1173-1181. PMID: 1254967

Flego M (2013) Clinical development of monoclonal antibody-based drugs in HIV and HCV diseases. BMC Med 11:4. https://dx.doi.org/10.1186\%2F1741-7015-11

Flyak AI, Ilinykh PA, Murin CD, Garron T, Shen X, Fusco ML, Hashiguchi T, Bornholdt ZA, Slaughter JC, Sapparapu G, Klages C, Ksiazek TG, Ward AB, Saphire
EO, Bukreyev A, Crowe JE Jr (2015) Mechanism of human antibody-mediated neutralization of Marburg virus. Cell 160:893-903.

https://doi.org/10.1016/j.cell.2015.01.031

Forsgren A, Brant M, Möllenkvist A, Muyombwe A, Janson H, Woin N, Riesbeck K. (2001) Isolation and characterization of a novel IgD-binding protein from Moraxella catarrhalis. J Immunol 167:2112-2120. https://doi.org/10.4049/jimmunol.167.4.2112

Geny B, Rodary C, Griscelli C, Mozziconacci P (1974) Immunoglobulin D (IgD) in childhood. I. Maturation of serum IgD: study of a population of healthy children. Biomedicine 20:40-45. PMID: 4858290

Haraldsson A, Weemaes CM, Jonasdottir S, Olafsson O, Van De Wiel G, Göertz J, Klasen I (2000) Serum immunoglobulin D in infants and children. Scand J Immunol 51:415-8. https://doi.org/10.1046/j.13653083.2000.00702.x

Heiner DC, Rose B (1970) A study of antibody responses by radioimmunodiffusion with demonstration of gamma $\mathrm{D}$ antigen-binding activity in four sera. J Immunol 104:691-697. PMID: 4190972

Huang J, Kang BH, Pancera M, Lee JH, Tong T, Feng Y, Imamichi H, Georgiev IS, Chuang GY, Druz A, DoriaRose NA, Laub L, Sliepen K, van Gils MJ, de la Peña AT, Derking R, Klasse PJ, Migueles SA, Bailer RT, Alam M, Pugach P, Haynes BF, Wyatt RT, Sanders RW, Binley JM, Ward AB, Mascola JR, Kwong PD, Connors M. (2014) Broad and potent HIV-1 neutralization by a human antibody that binds the gp41gp120 interface. Nature 515:138-142. https://doi.org/10.1038/nature13601

Hunyadi J, Hamerlinck F, Cormane RH (1976) Immunoglobulin and complement bearing polymorphonuclear leukocytes in allergic contact dermatitis and psoriasis vulgaris. Br J Dermatol 94:417422.

https://doi.org/10.1111/j.1365-2133.1976.tb06119.x

Jankowski A (1980) Immunoglobulin D in childhood. I. Serum level in healthy children. Arch Immunol Ther Exp 28:241-246. PMID: 7447636.

Jefferis R, Mathews JB (1977) Studies of human IgD myeloma proteins. Proteolytic digestion patterns. Immunochemistry 14:171-178. https://doi.org/10.1016/0019-2791(77)90191-4

Johansen FE, Baekkevold ES, Carlsen HS, Farstad IN, Soler D, Brandtzaeg P (2005) Regional induction of adhesion molecules and chemokine receptors explains disparate homing of human B cells to systemic and mucosal effector sites: dispersion from tonsils. Blood 106:593-600.

https://doi.org/10.1182/blood-2004-12-4630

Kikindjanin V (1981) IgD values in children suffering from acute, recurrent and chronic respiratory diseases. Allerg 
Immunol (Leipz); 27:203-206. PMID: 6462041

Klein F (2013) Antibodies in HIV-1 vaccine development and therapy. Science 341:1199-1204.

https://dx.doi.org/10.1126\%2Fscience.1241144

Korsrud FR, Brandtzaeg P (1980) Quantitative immunohistochemistry of immunoglobulin- and J-chain producing cells in human parotid and submandibular salivary glands. Immunology 39:129-140.

http://www.ncbi.nlm.nih.gov/pmc/articles/pmc1457971/

Korsrud FR, Brandtzaeg P (1981) Immunohistochemical evaluation of J-chain expression by intra- and extrafollicular immunoglobulin-producing human tonsillar cells. Scand J Immunol 13:271- 280.

https://doi.org/10.1111/j.1365-3083.1981.tb00135.x

Krawczyk A, Arndt MA, Grosse-Hovest L, Weichert W, Giebel B, Dittmer U, Hengel H, Jäger D, Schneweis KE, Eis-Hübinger AM, Roggendorf M, Krauss J (2013) Overcoming drug-resistant herpes simplex virus (HSV) infection by a humanized antibody. Proc Natl Acad Sci USA 110:6760-6765.

https://doi.org/10.1073/pnas.1220019110

Kwong PD, Mascola JR, Nabel GJ. (2013) Broadly neutralizing antibodies and the search for an HIV-1 vaccine: the end of the beginning. Nat Rev Immunol 13:693-701. https://doi.org/10.1038/nri3516

Lawrence DA, Weigle WO, Spiegelberg HL (1975) Immunoglobulins cytophilic for human lymphocytes, monocytes, and neutrophils. J Clin Invest 55:368-376. https://dx.doi.org/10.1172\%2FJCI107940

Lee SK, Metrakos JD, Tanaka KR, Heiner DC (1980) Genetic influence on serum IgD levels. Pediatr Res 14:60-63. https://doi.org/10.1203/00006450-19800100000014

Listi F, Candore G, Modica MA, Russo M, Di Lorenzo G, Esposito-Pellitteri M, Colonna-Romano G, Aquino, Bulati M, Lio D, Franceschi C, Caruso C (2006) A study of serum immunoglobulin levels in elderly persons that provides new insights into B cell immunosenescence. Ann N Y Acad Sci 1089:487-495. https://doi.org/10.1196/annals.1386.013

Litzman J, Ward A M, Wild G, Znojil V, Morgan G (1997) Serum IgD levels in children under investigation for and with defined immunodeficiency. Int Arch Allergy Immunol 114:54-58. https://doi.org/10.1159/000237643

Liu YJ, de Bouteiller O, Arpin C, Brière F, Galibert L, Ho S, Martinez-Valdez H, Banchereau J, Lebecque S (1996) Normal human IgD+IgM- germinal center B cells can express up to 80 mutations in the variable region of their IgD transcripts. Immunity 4:603-613.

https://doi.org/10.1016/s1074-7613(00)80486-0

Luster MI, Armen RC, Hallum JV, Leslie GA (1976) Measles virus-specific IgD antibodies in patients with subacute sclerosing panencephalitis. Proc Natl Acad Sci USA 73:1297-1299.
Lutz C, Ledermann B, Kosco-Vilbois MH, Ochsenbein AF, Zinkernagel RM, Kohler G, Brombacher F (1998) IgD can largely substitute for loss of IgM function in B cells. Nature 393 797e801. https://doi.org/10.1038/31716

Mosedale DE, Sandhu MS, Luan J, Goodall M, Grainger DJ (2006) A new sensitive and specific enzyme-linked immunosorbent assay for IgD. J Immunol Methods 313:74-80. https://doi.org/10.1016/j.jim.2006.03.012

Plebani A, Mira E, Mevio E, Monafo V, Notarangelo L D, Avanzini A, Ugazio AG. (1983) $\operatorname{IgM}$ and $\operatorname{IgD}$ concentrations in the serum and secretions of children with selective IgA deficiency. Clin Exp Immunol 53(3):689-696.

https://www.ncbi.nlm.nih.gov/pubmed/6616961

Preud'homme JL, Petit I, Barra A, Morel F, Lecron JC, Lelievre E (2000) Structural and functional properties of membrane and secreted IgD. Mol immunol 37: 871887. https://doi.org/10.1016/S0161-5890(01)00006-2

Qiu X (2014) Reversion of advanced Ebola virus disease in nonhuman primates with ZMapp. Nature 514:47-53. https://doi.org/10.1038/nature13777

Reichert JM (2015) Antibodies to watch in 2015. mAbs 7:1-8. https://doi.org/10.4161/19420862.2015.988944

Rigante D (2016) The truth on IgD in the ploy of immune surveillance and inflammation. Immunol Res 64:632-5. https://doi.org/10.1007/s12026-015-8744-z

Robbie GJ, Criste R, Dall'Acqua WF, Jensen K, Patel NK, Losonsky GA, Griffin MP (2013) A Novel Investigational Fc-Modified Humanized Monoclonal Antibody, Motavizumab-YTE, Has an Extended HalfLife in Healthy Adults. Antimicrob Agents Chemother 57(12): 6147-6153.

https://dx.doi.org/10.1128\%2FAAC.01285-13

Rogentine GN, Rowe DS, Bradley J, Waldmann TA, Fahey JL (1966) Metabolism of human immunoglobulin D (IgD). J Clin Invest 45 (9): 1467-78.

https://doi.org/10.1172/jci105454

Ronander E, Brant M, Janson H, Sheldon J, Forsgren A, Riesbeck K (2008) Identification of a novel Haemophilus influenzae protein important for adhesion to epithelial cells. Microb Infect 10:87-96. https://doi.org/10.1016/j.micinf.2007.10.006

Rostenberg I, Penaloza R (1978) Serum IgG and IgD and levels in some infectious and noninfectious diseases. Clinica Chimica Acta 85:319-321.

https://doi.org/10.1016/0009-8981(78)90310-8

Rowe DS, Crabbe PA, Turner MW (1968) Immunoglobulin D in serum, body fluids and lymphoid tissues. Clin Exp Immunol 3:477-490.

http://www.ncbi.nlm.nih.gov/pmc/articles/pmc1578945

Rowe DS, Fahey JL (1965a) A new class of human immunoglobulins. I. A unique myeloma protein. J Exp Med:171-184.

https://dx.doi.org/10.1084\%2Fjem.121.1.171 
Rowe DS, Fahey JL (1965b) A new class of human immunoglobulins. Ii. Normal serum IgD. J Exp Med 121:185-199. https://doi.org/10.1084/jem.121.1.185

Ruddick JH, Leslie GA (1977) Structure and biologic functions of human IgD. XI. Identification and ontogeny of a rat lymphocyte immunoglobulin having antigenic cross-reactivity with human IgD. J Immunol 118:10251031. PMID: 66267

Salonen EM, Hovi T, Meurman O, Vesikari T, Vaheri A (1985) Kinetics of specific $\operatorname{IgA}, \operatorname{IgD}, \operatorname{IgE}, \operatorname{IgG}$, and IgM antibody responses in rubella. $\mathrm{J}$ med virol 16:1-9. https://doi.org/10.1002/jmv.1890160102

Schroeder HW Jr, Cavacini L (2010) Structure and function of immunoglobulins. J Allergy Clin Immunol 125(2 Suppl 2):S41-S52.

https://dx.doi.org/10.1016\%2Fj.jaci.2009.09.046

Sewell HF, Chambers L, Maxwell V, Matthews JB, Jefferis $R$ (1978) The natural antibody response to E. coli includes antibodies of the IgD class. Clin Exp Immunol 31:104-110.

http://www.ncbi.nlm.nih.gov/pmc/articles/pmc1541194/

Sirisinha S, Charupatana C, Ramasoota T (1972) Serum immunoglobulins in leprosy patients with different spectra of clinical manifestations. Proc. Soc. Exp. Biol. Med 140:1062-1068. https://doi.org/10.3181/00379727140-36612

Stavnezer J, Guikema JE, Schrader CE (2008) Mechanism and regulation of class switch recombination. Annu Rev Immunol 26:261-292. https://doi.org/10.1146/annurev.immunol.26.021607.0902 48

Stenvik J, Schroder MB, Olsen K, Zapata A, Jorgensen TO (2001) Expression of immunoglobulin heavy chain transcripts (VH-families, IgM, and IgD) in head kidney and spleen of the Atlantic cod (Gadus morhua L.). Dev Comp Immunol 25:291-302.

https://doi.org/10.1016/s0145-305x(00)00056-2
Swierczynska Z, Wozniczko-Orlowska G, Maldyk H (1976) An IgD myeloma protein with antistreptolysin O activity. Immunochemistry 13:379-382.

https://doi.org/10.1016/0019-2791(76)90371-2

Tamma LSM, Wu Y, Toporovsky I, Lima V, Coico RF (2001) IgD receptor-mediated signal transduction in $\mathrm{T}$ cells. Cell immunol 207:110-117.

https://doi.org/10.1006/cimm.2000.1747

Tamma SM, Coico RF (2003) IgD-receptor (IgD-R) crosslinking partially protects murine $\mathrm{T}$ cells from dexamethasone-induced apoptosis. J Leukoc Biol 73:764-770. https://doi.org/10.1189/jlb.1002492

Tan Y (2015) A novel humanized antibody neutralizes H5N1 influenza virus via two different mechanisms. J Virol 89:3712-3722. https://doi.org/10.1128/JVI.03014-14

Tietz NW, Shuey DF, Wekstein DR (1992) Laboratory values in fit aging individuals-sexagenarians through centenarians. Clin Chem 38:1167-85. PMID: 1596990

Vacchelli E (2013) Trial watch: monoclonal antibodies in cancer therapy. Oncoimmunology 2:e22789. https://doi.org/10.4161/onci.22789

Vladutiu AO (2000) Immunoglobulin D: properties, measurement, and clinical relevance. Clin Diagn Lab Immunol 7:131-40. https://dx.doi.org/10.1128\%2Fcdli.7.2.131-140.2000

Walsh GM, Kay AB (1986) Binding of immunoglobulin classes and subclasses to human neutrophils and eosinophils. Clin Exp Immunol 63:466-472. PMID: 3698341

Wu Y, Tamma LSM, Lima V, Coico R (1999) Facilitated antigen presentation by $\mathrm{B}$ cells expressing $\mathrm{IgD}$ when responding $\mathrm{T}$ cells express IgD-receptors. Cell Immunol 192:194-202. https://doi.org/10.1006/cimm.1998.1453 